\title{
The Unfolded Protein Response Is a Major Mechanism by Which LRP1 Regulates Schwann Cell Survival after Injury
}

\author{
Elisabetta Mantuano, ${ }^{1}$ Kenneth Henry, ${ }^{1}$ Tomonori Yamauchi, ${ }^{1,3}$ Nobuhiko Hiramatsu, ${ }^{2}$ Kazuyo Yamauchi, ${ }^{1,3}$ \\ Sumihisa Orita, ${ }^{1,3}$ Kazuhisa Takahashi, ${ }^{3}$ Jonathan H. Lin, ${ }^{2}$ Steven L. Gonias, ${ }^{2}$ and W. Marie Campana ${ }^{1}$ \\ Departments of ${ }^{1}$ Anesthesiology and ${ }^{2}$ Pathology, University of California, San Diego, La Jolla, California 92093-0629, and ${ }^{3}$ Department of Orthopedic \\ Surgery, Graduate School of Medicine, Chiba University, Chiba 260-8670, Japan
}

In peripheral nerve injury, Schwann cells (SCs) must survive to exert a continuing and essential role in successful nerve regeneration. Herein, we show that peripheral nerve injury is associated with activation of endoplasmic reticulum (ER) stress and the adaptive unfolded protein response (UPR). The UPR culminates in expression of C/EBP homology protein (CHOP), a proapoptotic transcription factor in SCs, unless counteracted by LDL receptor-related protein-1 (LRP1), which serves as a major activator of phosphatidylinositol 3-kinase (PI3K). Sciatic nerve crush injury in rats induced expression of the ER chaperone GRP78/BIP, reflecting an early, corrective phase of the UPR. However, when LRP1 signaling was inhibited with receptor-associated protein, PI3K activity was decreased and CHOP protein expression increased, particularly in myelinating SCs. In cultured SCs, the PKR-like ER kinase target eIF2 $\alpha$ was phosphorylated and CHOP was induced by (1) inhibiting PI3K, (2) treating the cells with tumor necrosis factor- $\alpha$ (TNF- $\alpha$ ), or (3) genetic silencing of LRP1. CHOP gene deletion in SCs decreased cell death in response to TNF- $\alpha$. Furthermore, the effects of TNF- $\alpha$ on phosphorylated eIF $2 \alpha$, CHOP, and SC death were blocked by adding LRP1 ligands that augment LRP1-dependent cell signaling to PI3K. Collectively, our results support a model in which UPR-activated signaling pathways represent a major challenge to SC survival in nerve injury. LRP1 functions as a potent activator of PI3K in SCs and, by this mechanism, limits SC apoptosis resulting from increased CHOP expression in nerve injury.

\section{Introduction}

Multiple forms of cellular challenge induce protein misfolding in the endoplasmic reticulum (ER) and activate the unfolded protein response (UPR). In the UPR, unfolded proteins sequester the ER chaperone GRP78/BiP, causing activation of three transmembrane ER stress transducers (Ron and Walter, 2007). One transducer, PKR-like ER kinase (PERK), directly phosphorylates the $\alpha$-subunit of translation initiation factor-2 (eIF2). Phosphorylation of eIF $2 \alpha$ decreases protein synthesis, with a few exceptions, including the activating transcription factor 4 (ATF4) (Harding et al., 2000b). A major target for ATF4 is the C/EBP homology protein (CHOP) (Harding et al., 2002). Although many UPR mediators promote cell survival and recovery from ER stress, CHOP frequently induces cell death (Zinszner et al., 1998).

Pathways involved in cell survival, including the phosphatidylinositol 3-kinase (PI3K)-Akt mammalian target of rapamycin (mTOR) pathway, regulate eIF2 $\alpha$ and CHOP (Hyoda et al., 2006). Thus, CHOP and eIF $2 \alpha$ may provide an index of cell con-

Received June 7, 2011; revised July 7, 2011; accepted July 16, 2011.

Author contributions: E.M., T.Y., N.H., K.T., J.H.L.,S.L.G., and W.M.C. designed research; E.M., K.H., T.Y., N.H., K.Y., S.O., and W.M.C. performed research; E.M., K.H., T.Y., N.H., K.Y., S.O., K.T., J.H.L., S.L.G., and W.M.C. analyzed data; J.H.L., S.L.G., and W.M.C. wrote the paper.

This work was supported by NIH Grants R01 NS057456 (W.M.C.), R01 NS054571 (S.L.G.), and R01EY020846 (J.H.L.), the Uehara Memorial Foundation (K.Y., S.O.), and the University of California, San Diego Neuroscience Microscopy Shared Facility under NIH Grant P30NS047101. We thank Lori Graham for technical assistance.

Correspondence should be addressed to Dr. W. Marie Campana, Department of Anesthesiology, University of California, San Diego, 9500 Gilman Drive, MTF 447, La Jolla, CA 92093-0629. E-mail: wcampana@ucsd.edu.

DOI:10.1523/JNEUROSCI.2850-11.2011

Copyright $\odot 2011$ the authors $\quad 0270-6474 / 11 / 3113376-10 \$ 15.00 / 0$ dition and risk for apoptosis. There are exceptions in glia. In oligodendrocytes, $\mathrm{CHOP}$ promotes survival and modulates the severity of Pelizaeus-Merzbacher disease (Southwood et al., 2002). In models of Charcot-Marie-Tooth disease, CHOP controls the demyelinating activity of Schwann cells (SCs) (Pennuto et al., 2008). The role of CHOP as an adaptive cellular response mediator to stress should be viewed broadly and in a cell- and context-specific manner (Gow and Wrabetz, 2009).

In injury to peripheral nerve, SC activation, with the associated induction of injury-related genes and breakdown of myelin, is pivotal for generating an environment that supports axonal regrowth (Jessen and Mirsky, 2008). Survival of SCs early in the course of peripheral nerve injury is required for functional repair. Proper SC function may prevent chronic neuropathic pain (Campana, 2007). Studies have highlighted the importance of PI3K in SC survival (Campana et al., 1999; Li et al., 2001). The receptor systems controlling PI3K and its downstream targets in SCs remain unclear.

Low-density lipoprotein receptor-related protein-1 (LRP1) is a member of the LDL receptor gene family (Strickland et al., 2002). LRP1 is an endocytic and cell-signaling receptor for diverse ligands present in the injured PNS. These include the proteases matrix metalloprotease-9 (MMP-9), tissue-type plasminogen activator (tPA), and the extracellular matrix protein, fibronectin (La Fleur et al., 1996; Akassoglou et al., 2000). In the uninjured peripheral nerve, SCs express low levels of LRP1; however, after injury, LRP1 is rapidly upregulated (Campana et al., 2006). This is important because ligand binding to LRP1 in SCs results in robust cell signaling (Mantuano et al., 2008a) that is 
linked to cell survival, migration, and cytokine expression (Campana et al., 2006; Mantuano et al., 2008b; Shi et al., 2011). These activities are pivotal in SC phenotypic transformation during peripheral nerve regeneration.

Herein, we demonstrate that LRP1 plays a central role in sustaining PI3K activation in the injured peripheral nerve and in cultured SCs. When LRP1-dependent cell signaling is antagonized, PI3K activation is decreased, $\mathrm{CHOP}$ levels increase, and SC death is observed. SCs isolated from CHOP gene knock-out mice demonstrate enhanced survival when challenged with tumor necrosis factor- $\alpha$ (TNF- $\alpha$ ). Recombinant proteins, produced specifically to augment LRP1 signaling without off-target effects (Mettenburg et al., 2002; Mantuano et al., 2008b), blocked activation of the UPR and enhanced SC viability by further activating PI3K. We propose that UPR-related signaling pathways have the potential to play a major role in SC viability. These pathways are regulated intrinsically by LRP1 and therapeutically by engaging LRP1-dependent cell signaling.

\section{Materials and Methods}

Reagents. Receptor associated protein (RAP) was expressed as a glutathione-S-transferase fusion protein (GST-RAP) in bacteria and purified as described previously (Herz et al., 1991). As a control, we expressed GST in bacteria transformed with the empty vector pGEX-2T. The $\alpha_{2} \mathrm{M}$ receptor binding domain (RBD), which includes amino acids 1242-1451 of the mature $\alpha_{2} \mathrm{M}$ structure, was expressed as a GST fusion protein in bacteria, purified to homogeneity, and characterized for activity as described previously (Mettenburg et al., 2002; Mantuano et al., 2008a). A GST-fusion protein containing the hemopexin domain of human MMP-9 (PEX) was prepared and characterized as described previously (Mantuano et al., 2008b). All GST-fusion proteins and GST were subjected to endotoxin decontamination. Neurotrophin-3 (NT3) was purchased from Abcam. Catalytically inactive tPA was purchased from Molecular Innovations. Recombinant human TNF- $\alpha$ was purchased from R \& D Systems. The PI3K inhibitor LY294002 [2-(4-morpholinyl)8-phenyl-1(4H)-benzopyran-4-one] (LY) was from Calbiochem. Tunicamycin (TN) was from EMD Biosciences. Rabbit polyclonal antibodies for phospho-eIF $2 \alpha$ and phospho-p 85 PI3K and a monoclonal antibody for $\mathrm{CHOP}$ were purchased from Cell Signaling Technologies. A rabbit polyclonal antibody specific for LRP1 light chain and mouse monoclonal antibodies targeting $\beta$-actin or S100 were purchased from Sigma.

Nerve injury model systems. For nerve crush injury studies, C57BL/6J mice were purchased from Charles Rivers Laboratories and housed with a $12 \mathrm{~h}$ light/dark cycle and ad libitum access to food and water. For surgeries, mice were initially anesthetized with $4 \%$ isoflurane (IsoSol; VedCo) and maintained under $2 \%$ isoflurane. An incision was made through the skin below the hip. The muscle and fascia were blunt dissected using fine surgical scissors and forceps to expose the sciatic nerve. The sciatic nerve was crushed twice with flat forceps $(30 \mathrm{~s})$. The site of crush injury was then marked with an epineural suture. Mice were killed at 6,24 , and $72 \mathrm{~h}$ after crush injury by cervical dislocation under general anesthesia.

For sciatic nerve injection and axotomy experiments, adult male Sprague Dawley rats (225 g) were anesthetized with $4.5 \%$ isoflurane (IsoSol; VedCo) and maintained under $2.5 \%$ isoflurane. The left sciatic nerve was exposed at the sciatic notch. GST-RAP ( $2 \mu \mathrm{l}$ of a $25 \mu \mathrm{M}$ solution) was injected directly into the nerve using a Hamilton syringe with a 30 gauge needle (Wagner et al., 1998). In control studies, rats were injected with $2 \mu \mathrm{l}$ of GST ( $25 \mu \mathrm{M}$ ) or vehicle ( $20 \mathrm{~mm}$ sodium phosphate, 150 $\mathrm{mm} \mathrm{NaCl}, \mathrm{pH}$ 7.4, PBS) as described previously (Campana et al., 2006; Mantuano et al., 2008b). Nerves were immediately axotomized above the injection site. The muscle layer and skin were closed using 6.0 silk sutures. After $24 \mathrm{~h}$, animals were anesthetized. Some animals were perfused with $4 \%$ paraformaldehyde for immunohistochemistry (IHC) studies. The distal stumps of the axotomized nerves were removed, and the most proximal pieces $(0.5 \mathrm{~cm})$ were saved for analysis. Contralateral nerve was collected as a control. Rats were killed by an intraperitoneal injection of an overdose of ketamine (100 mg/kg; Phoenix Scientific) and xylazine (10 mg/kg; Boehringer Pharmaceutical). All animal research was performed according to protocols approved by the University of California, San Diego Committee on Animal Research and conform to the National Institutes of Health guidelines for animal use.

Primary Schwann cell cultures. Sciatic nerves were isolated from 1-dold Sprague Dawley rats, and SCs were further selected from fibroblasts using fibronectin-specific antibody and rabbit complement cytolysis, as described previously (Campana et al., 1998, 2006). The final preparations consisted of $98 \%$ SCs, as determined by immunofluorescence (IF) microscopy for S100, which is a specific SC marker. Primary cultures of SCs were maintained in DMEM containing 10\% FBS, $100 \mathrm{U} / \mathrm{ml}$ penicillin, $100 \mu \mathrm{g} / \mathrm{ml}$ streptomycin, $21 \mu \mathrm{g} / \mathrm{ml}$ bovine pituitary extract, and $4 \mu \mathrm{M}$ forskolin [complete medium (CM) ] at $37^{\circ} \mathrm{C}$ under humidified $5 \% \mathrm{CO}_{2}$. SC cultures were passaged no more than six times before conducting experiments.

SCs were isolated from 4-d-old B6.129S-Ddot3tm1Dron/J CHOP knock-out mice (Zinszner et al., 1998) and from C57BL/6J control mice. Primary cultures of mouse Schwann cells were obtained as described previously (Honkanen et al., 2007). Briefly, nerves were dissected and digested with trypsin and collagenase for $30 \mathrm{~min}$ at $37^{\circ} \mathrm{C}$. Cell suspensions were washed three times and resuspended in DMEM with $10 \%$ heat-inactivated horse serum (HS), $0.5 \mu \mathrm{m}$ forskolin (Calbiochem), 100 $\mathrm{U}$ penicillin, and $100 \mu \mathrm{g} / \mathrm{ml}$ streptomycin. Cells were plated on poly-Llysine and allowed to adhere overnight. After $48 \mathrm{~h}$, standard growth medium (DMEM, 10\% HS, $20 \mu \mathrm{g} / \mathrm{ml}$ bovine pituitary extract, $0.5 \mu \mathrm{M}$ forskolin, $100 \mathrm{U} / \mathrm{ml}$ penicillin, and $100 \mu \mathrm{g} / \mathrm{ml}$ streptomycin) was added. Medium was changed every other day. Complement-mediated cytolysis of contaminating fibroblasts was performed using CD90 anti-Thy-1.2 antibody (Serotec). The purity of mouse SC cultures was determined by S100 immunoreactivity and was $>90 \%$ for all presented studies.

LRP1 gene silencing. The previously described rat LRP1-specific siRNA (Campana et al., 2006) and non-targeting control (NTC) siRNA were purchased from Dharmacon. Primary cultures of SCs $\left(1 \times 10^{6}\right)$ were transfected with LRP1-specific or NTC siRNA ( $25 \mathrm{~nm}$ ) by electroporation using the Rat Neuron Nucleofector kit (Amaxa). The degree of LRP1 gene silencing was $\sim 95 \%$ at $24-72 \mathrm{~h}$ after electroporation as determined by real-time quantitative PCR ( $\mathrm{qPCR}$ ), immunoblot analysis, and RAP ligand blotting, as described previously (Campana et al., 2006). Cell signaling and Cell Death ELISA experiments were performed $36 \mathrm{~h}$ after introduction of siRNAs.

Real-time qPCR. DNA-free total RNA was extracted from frozen nerve tissue using TriZol (Invitrogen). Samples were purified and treated with DNase. cDNA was synthesized using the ProSTAR first-strand reverse transcriptase PCR kit (Stratagene). Expression of BIP and CHOP was measured by real-time qPCR using SYBR Green (Lin et al., 2007). RPL19 mRNA was used as a normalizing gene. The BiP primer sequences were 5'-CCTGCGTCGGTGTGTTCAAG-3' and 5' - AAGGGTCATTCCAAGTGCG-3'. The CHOP primer sequences were 5'-ACGGAAACAGAGTGGTCAGTGC-3' and $5^{\prime}$-CAGGAGGTGATGCCCACTGTTC-3'. The sequences of the RPL19 primers were 5'-ATGCCAACTCCCGTCAGCAG-3' and 5'-TCATCCTTCTCATCCAGGTCACC-3'. Expression of mouse TNF- $\alpha$ mRNA was determined using Taqman primers and probes purchased from Applied Biosystems The one-step program included $2 \mathrm{~min}$ at $50^{\circ} \mathrm{C}, 10 \mathrm{~min}$ at $95^{\circ} \mathrm{C}$, followed by 40 cycles of $95^{\circ} \mathrm{C}$ for $15 \mathrm{~s}$ and $60^{\circ} \mathrm{C}$ for $1 \mathrm{~min}$, using an ABI 7300 instrument. GAPDH mRNA levels were determined in each sample as a normalizing gene. We and others (Macdonald et al., 2001; Campana et al., 2006; Shubayev et al., 2006) have shown that GAPDH is an appropriate and relatively stable housekeeping gene in peripheral nerve injury. Samples without cDNA were analyzed as "no-template" controls. Samples were analyzed without treatment with reverse transcriptase to confirm the lack of genomic DNA contamination. All mRNA levels were determined in triplicate, in two to four separate experiments, and normalized against the $\mathrm{Ct}$ value for the housekeeping gene. mRNA levels were calculated by the comparative $\mathrm{Ct}$ method (Livak and Schmittgen, 2001).

Cell signaling and immunoblots. Primary cultures of rat SCs were plated in T25 flasks in CM and cultured until $\sim 85 \%$ confluent. The cells were then either retained in CM or treated with TN $(1.0 \mu \mathrm{g} / \mathrm{ml})$, LY $(20 \mu \mathrm{M})$, 
or TNF- $\alpha$ (50 ng/ml). In studies to examine PI3K activation, SCs were treated with NT3 (10 nM), RBD (10 nM), PEX (10 nM), or tPA (10 nM) for $10 \mathrm{~min}$. To assess the role of LRP1, GST-RAP (100 nM) or GST (100 nM) was added simultaneously with PI3K-activating agonists. At the end of experiments, cells were washed twice with ice-cold PBS. Cell extracts were prepared in RIPA buffer (PBS with $1 \%$ Triton X-100, 0.5\% sodium deoxycholate, $0.1 \%$ SDS, proteinase inhibitor mixture, and sodium orthovanadate). GST- and RAP-treated sciatic nerves also were extracted in RIPA buffer. The protein concentration in cell and nerve extracts was determined by bicinchoninic acid assay. An equivalent amount of cellular protein $(50 \mu \mathrm{g})$ was subjected to SDS-PAGE and electrotransferred to nitrocellulose membranes. The membranes were blocked with 5\% nonfat dry milk in Tris-HCl-buffered saline, $\mathrm{pH}$ 7.4, with Tween 20 and incubated with the primary antibodies to detect phospho-eIF2 $\alpha$, phospho-p85 PI3K, CHOP, LRP1, or $\beta$-actin. The membranes were washed and treated with horseradish peroxidaseconjugated secondary antibodies for $1 \mathrm{~h}$. Immunoblots were developed using enhanced chemiluminescence (GE Healthcare).

Cell death studies. SCs (mouse or rat) were plated at 10,000 cells per well in 96-well plates. Cells were allowed to attach overnight in CM. The cells were then retained in CM, transferred to DMEM containing $0.5 \%$ FBS [low serum medium (LSM)], or treated with TNF- $\alpha(50 \mathrm{ng} / \mathrm{ml})$ in LSM for $18 \mathrm{~h}$. In some cases, SCs were pretreated with NT3 (10 nM), RBD $(10 \mathrm{~nm})$, PEX (10 nM), or tPA (10 nM) before adding TNF- $\alpha(50 \mathrm{ng} / \mathrm{ml})$. GST-RAP or GST was added simultaneously with the LRP1 agonists. Studies also were performed using LRP1-specific siRNA- or NTCtransfected cells. Cell death was measured using the Cell Death ELISA (Roche), a colorimetric assay that detects intracytoplasmic oligonucleosomes (Myers et al., 2003).

IF, IHC, and microscopy. In SC IF microscopy studies, SCs in culture were fixed with fresh $4 \%$ paraformaldehyde in $0.1 \mathrm{~m}$ sodium phosphate, $\mathrm{pH} 7.4$, for $10 \mathrm{~min}$ at $22^{\circ} \mathrm{C}$. Cells were permeabilized with $0.3 \%$ Triton $\mathrm{X}-100 / \mathrm{PBS}$. Nonspecific binding sites were blocked with 1\% BSA, $2 \%$ heat-inactivated $\mathrm{HS}$ in PBS for $30 \mathrm{~min}$ at $22^{\circ} \mathrm{C}$. Cells then were incubated overnight at $4^{\circ} \mathrm{C}$ with primary antibodies in $0.2 \%$ BSA, $0.4 \%$ heatinactivated HS in PBS. Next, cells were incubated with Alexa Fluor 488or 564-conjugated secondary antibodies in $0.2 \%$ BSA, $0.4 \%$ HS in PBS for $1 \mathrm{~h}$ at $22^{\circ} \mathrm{C}$. For dual-labeling studies, a second set of primary and secondary antibodies were added. Preparations were mounted on slides using Pro-long Gold with DAPI for nuclear labeling. Images were captured on an Olympus Fluoview 1000 confocal microscope.

To examine $\mathrm{CHOP}$ in sciatic nerves by IHC, anesthetized animals were perfused with fresh $4 \%$ paraformaldehyde containing $0.1 \mathrm{~m}$ phosphate buffer, $\mathrm{pH}$ 7.4. Sciatic nerves were removed, postfixed in perfusate, and processed for paraffin embedding as described previously (Wagner et al., 1998). Sections were cut $(4 \mu \mathrm{m})$ and incubated with Tris-EDTA (Ventana Discovery Ultra Medical Systems) for 4 and 8 min cycles at $95^{\circ} \mathrm{C}$. Nonspecific binding was blocked with $10 \%$ nonfat milk. Primary antibodies (CHOP, 1:500) were subsequently incubated in antibody diluent (Dako) for $1 \mathrm{~h}$ at $22^{\circ} \mathrm{C}$. Next, sections were incubated with anti-mouse antibodies conjugated to HRP (Ventana Discovery Ultra Medical Systems) and developed with $3^{\prime} 3$ diaminobenzidine. Some sections were treated with secondary antibody only, as a control. Imaging was performed using a Leica DCF2500 microscope with Leica imaging software 2.8.1. Images were obtained using a $63 \times$ objective.

Statistical analysis. In all experiments, replicates refer to separate experiments, typically performed with internal duplicates or triplicates. Results of cell death experiments were subjected to $t$ test or a one-way ANOVA. Tukey's post hoc analysis was used to assess differences between treatment groups.

\section{Results}

\section{The UPR is activated in crush-injured peripheral nerves}

In PNS injury, SCs become activated; injury-related genes are expressed, phagocytosis is increased, and growth factor secretion is stimulated (Jessen and Mirsky, 2008). To begin, we tested whether sciatic nerve crush injury promotes expression of GRP78/BIP. This ER resident chaperone is expressed early in the
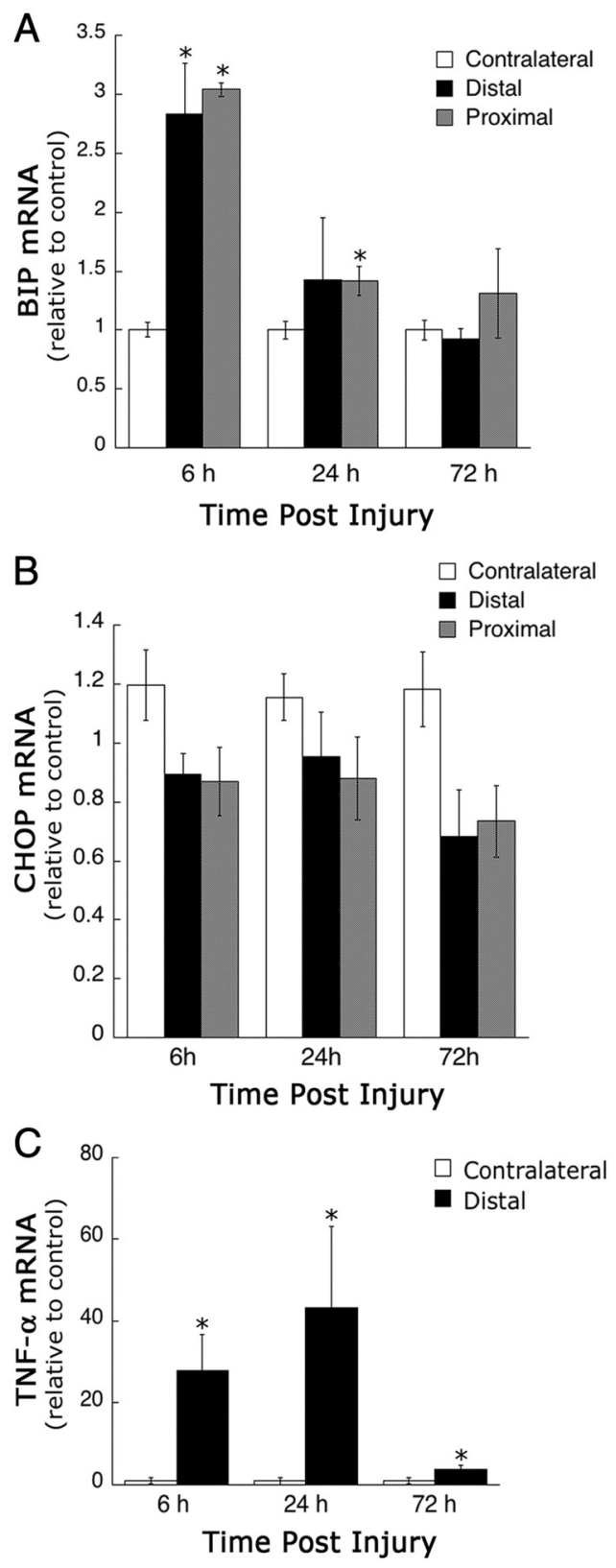

Figure 1. Induction of the unfolded protein response (UPR) after peripheral nerve injury. $\boldsymbol{A}$ BIP/GRP78 mRNA levels in crush injured sciatic nerve segments. $\boldsymbol{B}$, CHOP mRNA levels in crush injured sciatic nerve segments. $C$, TNF- $\alpha$ mRNA levels in crush injured sciatic nerve segments. mRNA levels were determined in contralateral, distal, and proximal nerve by qPCR 6, 24, and $72 \mathrm{~h}$ after crush. Data are expressed as fold increase (mean \pm SEM) compared with mRNA levels in contralateral nerve ${ }^{*} p<0.05$ ( $n=2-4$ animals per group).

UPR, as a corrective measure before the cell activates proapoptotic pathways (Ron and Walter, 2007). In sciatic nerves, SCs account for $>90 \%$ of the mRNA except late in the course of nerve injury when inflammatory cell infiltration becomes extensive (Asbury and Johnson, 1978). Figure $1 A$ shows that the mRNA level for GRP78/BIP was significantly increased $6 \mathrm{~h}$ after crush injury, proximal and distal to the crush injury site, compared with the uninjured contralateral nerve. By 72 h, GRP78/BIP mRNA levels returned to baseline. GRP78/BIP mRNA in the contralateral nerve was unchanged over the $72 \mathrm{~h}$ time course.

CHOP mRNA expression was not increased in the crushinjured sciatic nerve (Fig. $1 B$ ), suggesting that cell-signaling 
A

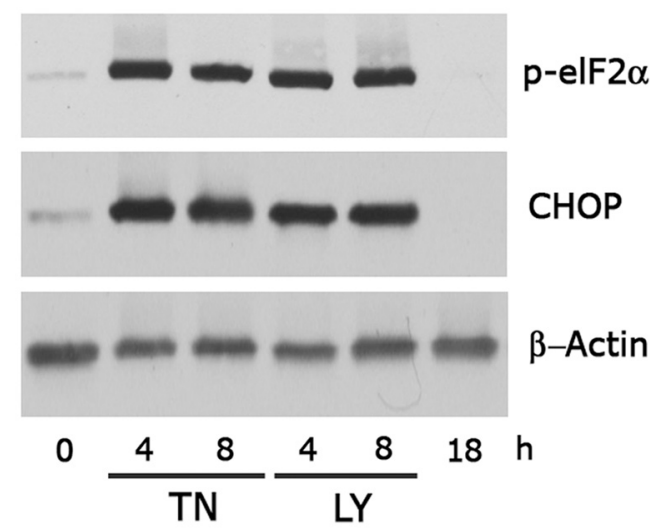

B
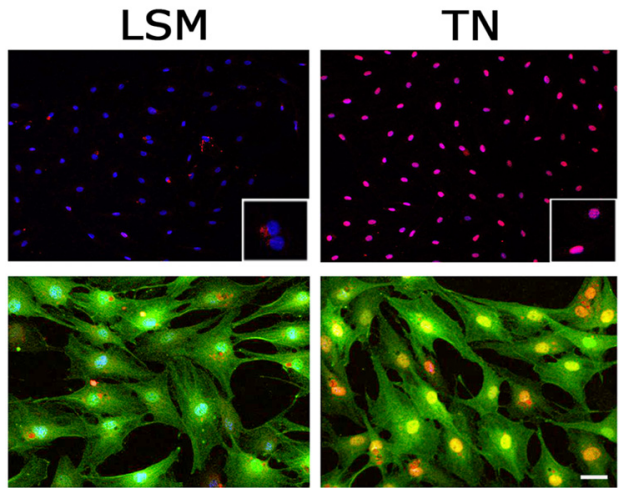

Figure 2. Induction of the UPR in primary SCS. A, Immunoblot analysis of p-elF $2 \alpha$ and CHOP in primary cultured SCs. SCs were treated in CM for 0 or $18 \mathrm{~h}$ or in $0.5 \% \mathrm{LSM}$ with TN $(1 \mu \mathrm{g} / \mathrm{ml})$ or LY $(20 \mu \mathrm{m})$ for 4 or $8 \mathrm{~h}$. Equal amounts of cellular protein $(50 \mu \mathrm{g})$ were loaded into each lane, subjected to SDS-PAGE, and electrotransferred to nitrocellulose for detection with specific antibodies. $\beta$-Actin was used as a loading control. Each blot represents at least two to five independent experiments. $\boldsymbol{B}$, Immunofluorescence of CHOP in primary cultured SCS. SCS were treated in LSM or TN for $4 \mathrm{~h}$. The top row shows CHOP (red) and DAPI (blue). The bottom row shows CHOP, S100, a Schwann cell marker (green), and DAPI. Scale bar, $10 \mu \mathrm{m}$.

pathways may be activated in SCs in the injured PNS that counteract progression of the UPR. Previous studies have demonstrated that TNF- $\alpha$ functions as a major inflammatory mediator early in peripheral nerve injury (Sommer and Schäfers, 1998; Kleinschnitz et al., 2004). Figure $1 C$ confirms that, in our experiments, TNF- $\alpha$ mRNA expression was substantially increased distal to the injury site in crush-injured sciatic nerves.

\section{CHOP is expressed in response to stress in cultured SCs}

In response to sustained ER stress, PERK is activated and phosphorylates eIF $2 \alpha$, leading to increased expression of CHOP (Zinszner et al., 1998; Harding et al., 2000a; Lin et al., 2007, 2009). To study this cell-signaling pathway, we initially treated primary cultures of rat SCs (Campana et al., 1999, 2006) with the glycosylation inhibitor TN, which is known to induce the UPR. Figure $2 \mathrm{~A}$ shows that eIF2 $\alpha$ was phosphorylated and CHOP protein levels were substantially increased 4 and $8 \mathrm{~h}$ after addition of TN. Activation of the UPR is regulated by diverse cell-signaling factors, including PI3K and PTEN (phosphatase and tensin homolog) (Hyoda et al., 2006; Mounir et al., 2009). Figure $2 \mathrm{~A}$ shows that, in the absence of TN, the PI3K inhibitor LY $(20 \mu \mathrm{M})$ increased phospho-eIF $2 \alpha$ and CHOP protein levels; the extent of the response was similar to that observed with TN.

In IF microscopy studies, CHOP was observed in essentially all of the SCs and localized almost exclusively to the nucleus after TN treatment (Fig. 2B, top). Dual labeling with S100 (Fig. 2B,

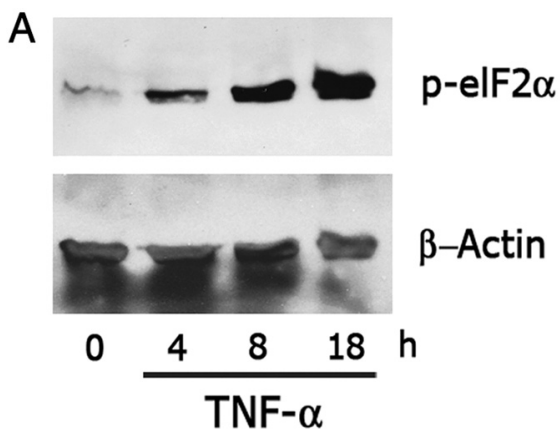

B

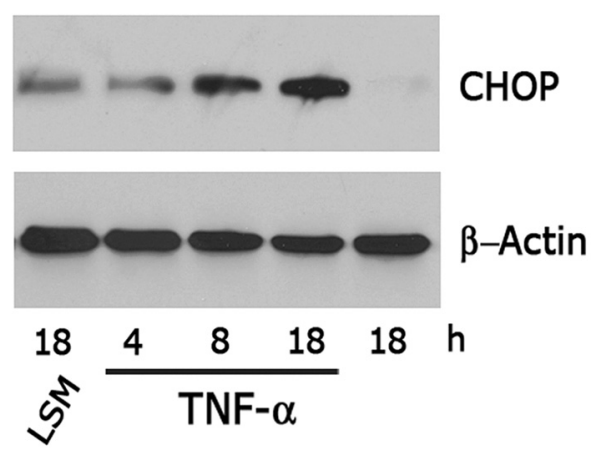

Figure 3. Induction of UPR in primary SCs by the proinflammatory cytokine TNF $\alpha$. A, Immunoblot analysis of p-elF $2 \alpha$ after treatment with LSM and TNF- $\alpha(50 \mathrm{ng} / \mathrm{ml})$ for 0,4 , and $18 \mathrm{~h}$. $\boldsymbol{B}$, Immunoblot analysis of CHOP after treatment with LSM (18 h), LSM and TNF- $\alpha(50 \mathrm{ng} / \mathrm{ml})$ for 4 , 8 , and $18 \mathrm{~h}$, or CM (18 h). Equal amounts of cellular protein $(50 \mu \mathrm{g}$ ) were loaded into each lane, subjected to SDS-PAGE, and electrotransferred to nitrocellulose for detection with specific antibodies. $\beta$-Actin was used as a loading control. Each blot represents at least two to five independent experiments.

bottom) showed that TN induced morphological evidence of cell stress in SCs, including flattening and shortening of cellular processes. Although nearly all of the cells in the dual-labeled preparation showed evidence of $\mathrm{CHOP}$ accumulation in the nucleus (yellow or orange staining nuclei), the most robustly CHOPpositive cells (orange nuclei) were frequently poorly attached to the substratum and demonstrated decreased S100 immunopositivity. We interpret these results as evidence of a highly stressed state.

SCs that were treated with TNF- $\alpha$ demonstrated increased phospho-eIF $2 \alpha$, as determined by immunoblot analysis; however, the response developed gradually over $18 \mathrm{~h}$ (Fig. $3 A$ ). Similar results were obtained when we examined CHOP levels. At $4 \mathrm{~h}$, when maximum responses were already apparent with TN and LY, CHOP protein levels were unchanged by TNF- $\alpha$ (Fig. $3 B$ ). In cells that were treated with TNF- $\alpha$ for $18 \mathrm{~h}$, CHOP levels were substantially increased. CHOP was modestly increased in SCs that were cultured in $0.5 \%$ FBS-containing medium (LSM) compared with cells maintained in 10\% FBS-containing medium (CM) for $18 \mathrm{~h}$.

\section{CHOP promotes SC apoptosis}

Although generally considered a proapoptotic transcription factor, $\mathrm{CHOP}$ has been reported to express alternative activities in glia (Southwood et al., 2002; Pennuto et al., 2008). To test whether CHOP is proapoptotic in SCs, primary cultures were established from $\mathrm{CHOP}$ gene knock-out mice and from control mice with the identical genetic background. After complementmediated cytolysis, mouse SC identity was confirmed by S100 labeling and represented $>90 \%$ of the primary culture (Fig. $4 \mathrm{~A}$ ). 


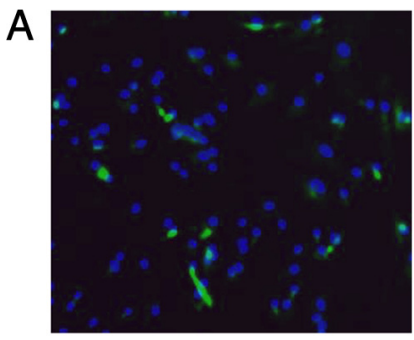

pre-purification

B

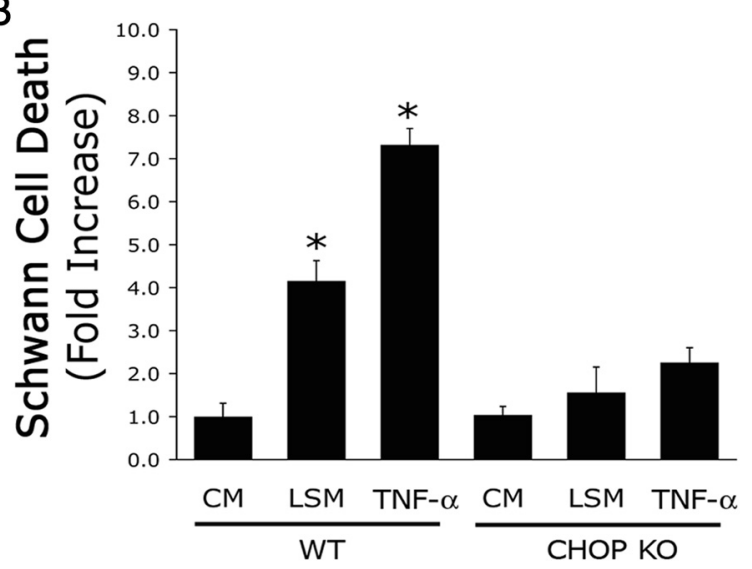

Figure 4. CHOP promotes SC apoptosis. $\boldsymbol{A}$, Immunofluorescence microscopy of $\mathrm{S} 100$ (green) and DAPI (blue) in primary cultured mouse SCs during purification. $\boldsymbol{B}, \mathrm{SC}$ death in wild-type (WT) or CHOP knock-out (CHOP KO) mice in vitro. Cells were cultured in CM, LSM, or in LSM supplemented with TNF- $\alpha(50 \mathrm{ng} / \mathrm{ml})$ for $18 \mathrm{~h}$. Cell death was measured using the Cell Death ELISA, which detects intracytoplasmic oligonucleosomes. The absolute absorbance values were $0.1 \pm 0.2$ for CM, $0.6 \pm 0.1$ for LSM, and $1.2 \pm 0.2$ for TNF- $\alpha$. Data are expressed as fold increase mean \pm SEM ( $n=4$ per group). ${ }^{*} p<0.05$ compared with complete media. Scale bars, $15 \mu \mathrm{m}$.

Cells were cultured in LSM or in LSM supplemented with TNF- $\alpha$ $(50 \mathrm{ng} / \mathrm{ml})$ for $18 \mathrm{~h}$. Cell death was measured using the Cell Death ELISA.

SCs from wild-type mice that were exposed to LSM or treated with TNF- $\alpha$ demonstrated 4.0-fold and 8.0-fold increases in cell death, respectively, compared with cells maintained in CM (Fig. $4 B$ ). This corresponded to absolute absorbance value of $0.130 \pm$ 0.022 for cells in CM and represented $\sim 10,000$ cells. Previous studies in which rat SCs in culture were exposed to LSM or treated with TNF- $\alpha$ generated similar results (Campana et al., 1999, 2006). In response to LSM or TNF- $\alpha$, SCs from CHOP gene knock-out mice demonstrated significantly decreased cell death. These results suggest that $\mathrm{CHOP}$ is death promoting in SCs that are challenged by TNF- $\alpha$ or serum deprivation.

\section{Regulation of PI3K in SCs}

The PI3K-Akt pathway plays a major role in SC survival (Campana et al., 1999; Weiner and Chun, 1999; Brunet et al., 2001). Our previous studies demonstrated that LRP1 may be an important regulator of PI3K activation because LRP1 gene silencing in SCs decreased the basal level of phospho-Akt (Campana et al., 2006). To further elucidate the role of LRP1 as a regulator of PI3K, we performed new studies examining phosphorylation of the PI3K p85 subunit (p-PI3K). Figure 5A shows that, in SCs cultured in LSM, LRP1 gene silencing substantially decreased the basal level of p-PI3K.

To study the role of LRP1 as a regulator of PI3K in vivo, we injected the LRP1 antagonist GST-RAP ( $2 \mu \mathrm{l}$ of $25 \mu \mathrm{M}$ solution $)$
A
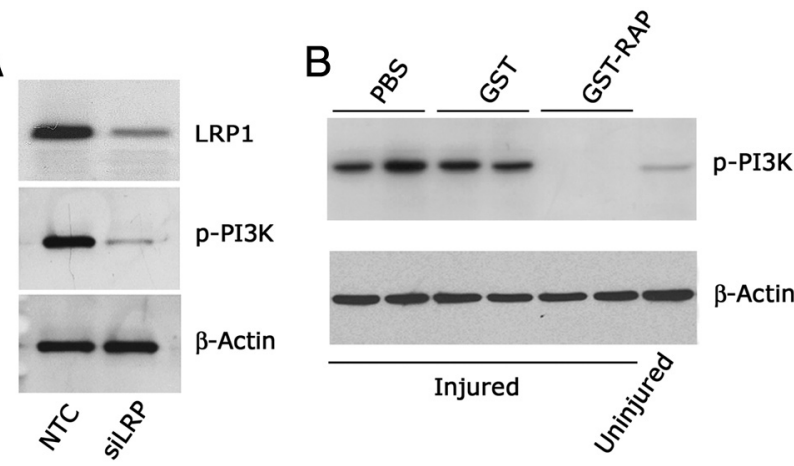

C
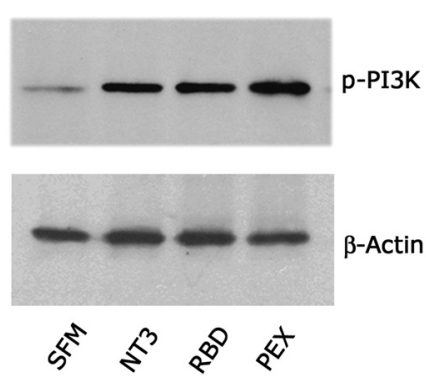

Figure 5. $\quad \mathrm{LRP1}$ regulates $\mathrm{PI} 3 \mathrm{~K}$ signaling in primary $\mathrm{SC}$. $\boldsymbol{A}$, Immunoblot analysis of $\mathrm{p}-\mathrm{PI} 3 \mathrm{~K}$ and LRP1 in primary cultured SCs transfected with NTC or LRP1-specific siRNA. $\boldsymbol{B}$, Immunoblot analysis of p-PI3K in uninjured or axotomized rat sciatic nerves injected with $2 \mu$ of PBS, GST $(25 \mu \mathrm{m})$, or GST-RAP $(25 \mu \mathrm{m})$ before axotomy. Nerves were collected and lysed in RIPA buffer after $24 \mathrm{~h}$. C, Immunoblot analysis of p-PI3K in primary cultured SCs treated with serum-free media (SFM) or serum-free media supplemented with NT3 (10 nm), RBD (10 nm), or PEX (10 nm) for $10 \mathrm{~min}$. Equal amounts of cellular protein $(50 \mu \mathrm{g})$ were loaded into each lane, subjected to SDS-PAGE, and electrotransferred to nitrocellulose for detection with specific antibodies. In all studies, $\beta$-actin was used as a loading control. Each blot represents three independent studies.

into sciatic nerves that were then immediately axotomized. GSTRAP binds directly to LRP1, inhibiting binding of most endogenous LRP1 ligands (Willnow et al., 1996; Strickland et al., 2002) without activating LRP1-dependent cell signaling (Mantuano et al., 2008b). As a control, we also injected GST or PBS. Previously, we demonstrated that GST-RAP induces SC death in this model system (Campana et al., 2006). Figure 5B shows that GST-RAP substantially decreased $\mathrm{p}$-PI3K in axotomized nerves compared with nerves that were injected with PBS or GST.

We hypothesized that the results presented in Figure 5, $A$ and $B$, reflect LRP1 signaling induced by ligands produced endogenously by SCs in culture or in the injured sciatic nerve. Figure $5 C$ shows that treatment of SCs with purified LRP1 ligands for 10 min further activated PI3K. The LRP1 agonists studied in Figure $5 C$ included the isolated LRP1-binding domain of $\alpha_{2} \mathrm{M}$ (RBD) (Mantuano et al., 2008a) and the isolated hemopexin domain of MMP-9 (PEX) (Mantuano et al., 2008b). The level of p-PI3K observed in RBD- or PEX-treated cells was similar to that observed in cells treated with NT3, which is a well-described prosurvival factor in SCs (Meier et al., 1999; Chan et al., 2001).

\section{LRP1 ligands block TNF $\alpha$-mediated apoptosis}

The function of LRP1 ligands as potent activators of PI3K raised the hypothesis that these agents may function as prosurvival signals for SCs. To test this hypothesis, SCs were treated with PEX (10 nM), RBD (10 nM), or tPA (10 nM) for 10 min before adding TNF- $\alpha$ for $18 \mathrm{~h}$. Cells also were pretreated with NT3, as a positive control. When added alone, TNF- $\alpha$ induced a significant increase (7.0-fold) in SC death (Fig. 6A). All three LRP1 ligands significantly decreased the level of cell death, as did NT3. 
A
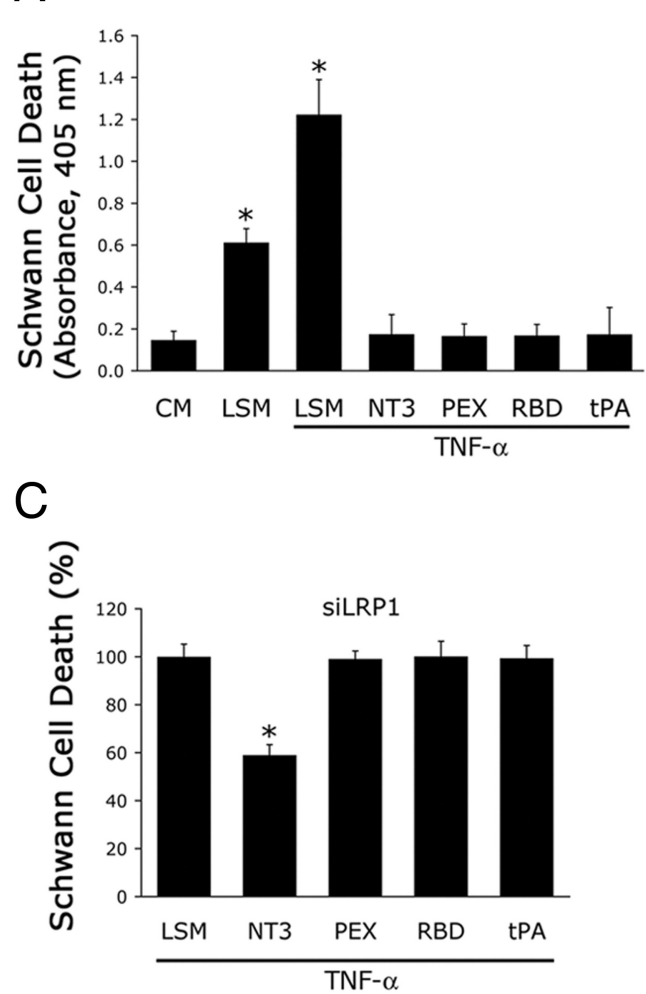

$\mathrm{B}$

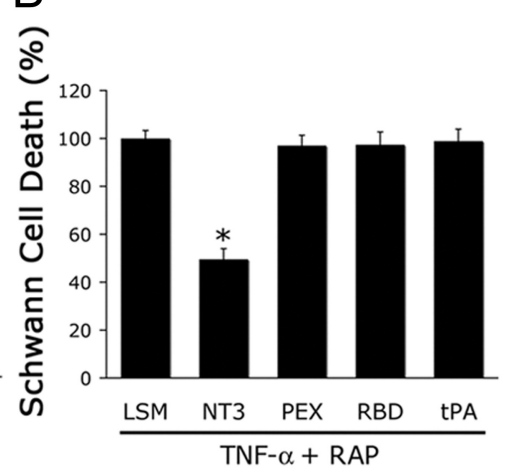

$\mathrm{D}$

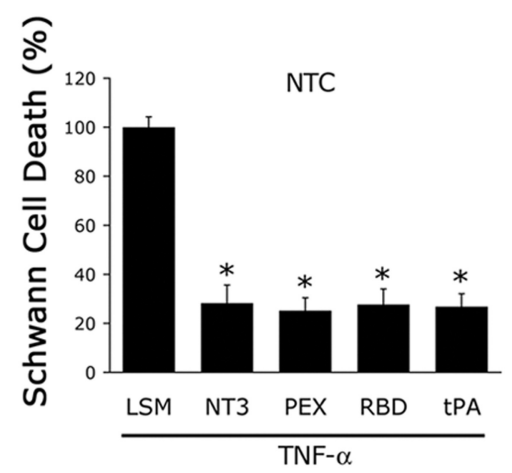

Figure 6. LRP1 ligands block TNF- $\alpha$-mediated apoptosis. SC death was measured using the Cell Death ELISA. $\boldsymbol{A}$, Schwann cells were treated with NT3 (10 nM), PEX (10 nm), RBD (10 nM), or tPA (10 nm) in LSM for 15 min before the addition of TNF- $\alpha$ ( $50 \mathrm{ng} / \mathrm{ml})$ for $18 \mathrm{~h}$. Data are expressed as mean \pm SEM. ${ }^{*} p<0.05$ fold increase compared with cells cultured in CM. $\boldsymbol{B}$, Schwann cells were treated with GST-RAP (100 nm) at the same time as NT3 (10 nm), RBD (10 nm), or tPA (10 nm) in LSM. TNF- $\alpha$ (50 ng/ml) was subsequently added for $18 \mathrm{~h}$. Data are expressed as mean \pm SEM percent of $L S M\left(n=4\right.$ per group, $\left.{ }^{*} p<0.05\right)$. C, D, Schwann cells were transfected with LRP1-specific siRNA or NTC and pretreated with PEX (10 nм), RBD (10 nм), or tPA (10 nm) for 10 min in LSM before adding TNF- $\alpha(50 \mathrm{ng} / \mathrm{ml})$ for $18 \mathrm{~h}$. Data are expressed as mean \pm SEM percent of LSM ( $n=4$ per group, $\left.{ }^{*} p<0.05\right)$.

caspase-3. Caspase-3 is an executioner caspase, functioning in both the intrinsic and extrinsic apoptosis pathways (Thornberry and Lazebnik, 1998). Caspase-3 also is activated in late stages of the UPR, as a mechanism of proapoptotic signaling (Oyadomari and Mori, 2004). Figure 7 shows that cleaved caspase-3 was minimally present in cells maintained in CM. However, when SCs were treated with TNF- $\alpha$ in LSM, cleaved caspase- 3 was present in $35 \%$ of the cells $(p<0.05)$. Treatment of the SCs with PEX, RBD, or tPA before TNF- $\alpha$ counteracted the effects of TNF- $\alpha$ on caspase- 3 activation.

\section{LRP1-initiated cell signaling blocks CHOP expression in SCs}

Given the known role of PI3K in counteracting UPR-triggered signaling pathways (Winnay et al., 2010), we studied the effects of LRP1 ligands on p-eIF $2 \alpha$ and CHOP. Figure $8 A$ shows that $\mathrm{PA}, \mathrm{RBD}$, and PEX did not independently regulate p-eIF $2 \alpha$ or CHOP; however, each LRP1 ligand blocked the increase in p-eIF $2 \alpha$ and CHOP associated with TNF- $\alpha$ treatment. Figure $8 B$ shows that RAP reversed the activity of the $\mathrm{RBD}, \mathrm{PEX}$, and $\mathrm{TPA}$, in the presence of TNF- $\alpha$, so that p-eIF $2 \alpha$ and CHOP were once again increased.

To further explore the relationship between LRP1 and CHOP as regulators of SC survival, we performed cell death assays using SCs isolated from CHOP gene knock-out mice and wild-type mice of the

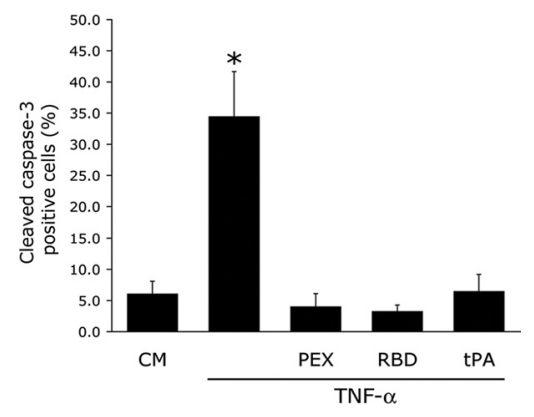

Figure 7. LRP1 ligands block activation of cleaved caspase-3. Schwann cells were cultured in CM, LSM, or LSM and PEX (10 nM), RBD (10 nM), or PA (10 nm) for 10 min before adding TNF- $\alpha$ $(50 \mathrm{ng} / \mathrm{ml})$ for $18 \mathrm{~h}$. Immunofluorescence microscopy was performed to detect cleaved caspase3-positive cells. Cleaved caspase-3-positive Schwann cells were counted and expressed as a percentage of DAPI-positive cells.

To confirm that the effects of RBD, PEX, and tPA were mediated by LRP1, first, we treated cells with GST-RAP. GST-RAP completely blocked the ability of the LRP1 ligands to prevent the proapoptotic activity of TNF- $\alpha$ (Fig. $6 B$ ). NT3 was still active in the presence of GST-RAP, as anticipated. LRP1 gene silencing also neutralized the activity of the RBD, PEX, and tPA (Fig. 6C). As shown in Figure $6 D$, all three LRP1 ligands were protective in cells that were transfected with NTC siRNA, as anticipated.

As a second method to demonstrate that LRP1 ligands promote SC survival, IF microscopy was performed to detect cleaved same genetic background. In wild-type mice, TNF- $\alpha$ induced an eightfold increase in cell death, and this was counteracted by PEX, RBD, or NT3. GST-RAP blocked the ability of PEX and RBD to inhibit the death-promoting activity of TNF- $\alpha$. SCs from CHOP gene knock-out mice demonstrated less cell death in response to TNF- $\alpha$, as was reported in Figure 4. PEX and RBD counteracted the residual effects of TNF- $\alpha$ on cell death, and this was inhibited by GST-RAP. These results support a model in which LRP1 promotes SC survival by inhibiting induction of $\mathrm{CHOP}$ and by CHOP-independent pathways.

\section{LRP1 regulates $\mathrm{CHOP}$ by activating $\mathrm{PI} 3 \mathrm{~K}$}

In addition to PI3K, LRP1 activates ERK1/2, which is a potent prosurvival cell-signaling factor (Mantuano et al., 2008a). To test the mechanism by which LRP1 regulates CHOP, we examined the effects of PEX, RBD, and tPA in cells that were treated with TNF- $\alpha$ and LY. Although LRP1 ligands blocked the increase in CHOP observed in response to TNF- $\alpha$ treatment alone (Fig. 8), these reagents were completely ineffective in the presence of LY (Fig. 9A). These results suggest that, when the effects of LRP1 on PI3K activation are blocked, alternative LRP1-activated cellsignaling pathways are ineffective at regulating $\mathrm{CHOP}$. To test this model, we examined p-eIF2 $\alpha$ and CHOP in SCs in which LRP1 was silenced. As shown in Figure 9B, LRP1 gene silencing was sufficient to induce p-eIF2 $\alpha$ and CHOP.

To test whether LRP1 is important in preventing progression of the UPR in injured sciatic nerves, we injected RAP ( $2 \mu$ l of 25 
A

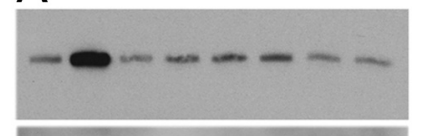

B

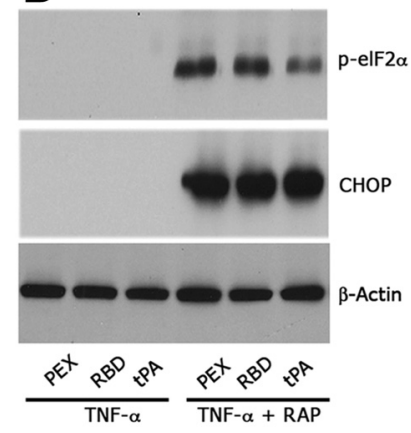

C

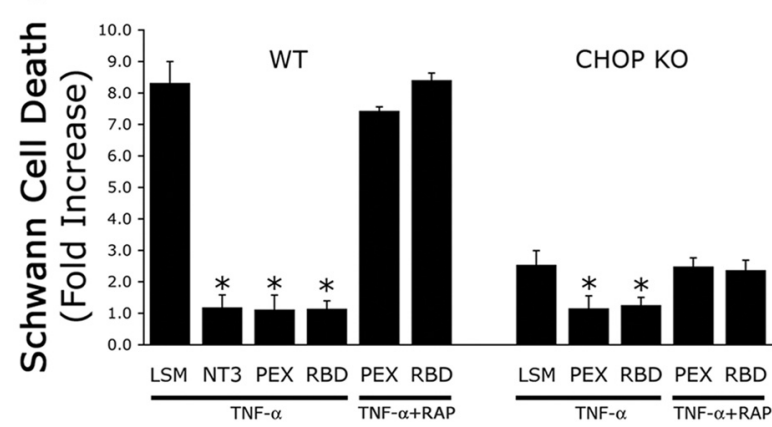

Figure 8. LRP1-dependent cell signaling blocks the UPR and apoptosis in primary SCS. $\boldsymbol{A}, \boldsymbol{B}$, Immunoblot analysis of $\mathrm{p}$-elF $2 \alpha$ and CHOP in primary Schwann cells cultured in CM, LSM, or LSM and PEX (10 nM), RBD (10 nM), or tPA (10 nm) with or without GST-RAP (100 nM) for $10 \mathrm{~min}$ before adding TNF- $\alpha(50 \mathrm{ng} / \mathrm{ml})$ for $18 \mathrm{~h}$. Equal amounts of cellular protein $(50 \mu \mathrm{g})$ were loaded into each lane, subjected to SDS-PAGE, and electrotransferred to nitrocellulose for detection with specific antibodies. $\beta$-Actin was used as a loading control. Each blot represents at least two to three independent studies. $C$, Schwann cell death was measured using Cell Death ELISA. Schwann cells from wild-type (WT) and CHOP knock-out (CHOP KO) mice were cultured in LSM or LSM and NT3 (10 nM), PEX (10 nM), or RBD (10 nm) with or without GST-RAP (100 nm) for $10 \mathrm{~min}$ before adding TNF- $\alpha(50 \mathrm{ng} / \mathrm{ml})$ for $18 \mathrm{~h}$. Data are expressed as fold increase compared with CM (mean \pm SEM). ${ }^{*} p<0.05$ compared with LSM ( $n=4$ per group).

$\mu \mathrm{M}$ solution) directly into nerves that were then immediately axotomized. CHOP protein levels were increased by RAP treatment, as determined by immunoblot analysis (Fig. 9C). In IHC studies, CHOP immunoreactivity was substantially increased in RAPtreated Schwann cells distal to the crush injury site (Fig. 9D). CHOP was detected at substantially decreased levels in sciatic nerves that were injected with GST or PBS, as controls. Diffuse immunostaining for CHOP in the background of RAP-treated sciatic nerves probably reflected CHOP that was lost to the extracellular space as a result of cell injury and/or death because similar immunoreactivity was not observed in GST- or PBS-injected nerves.

\section{Discussion}

SC survival immediately after peripheral nerve injury is essential for nerve regeneration (Meier et al., 1999; Jessen and Mirsky, 2005) and perhaps for preventing development of chronic pain states (Campana, 2007). When activated by injury, SCs synthesize growth factors (Meyer et al., 1992; Zhang et al., 2000; Li et al., 2005) and extracellular matrix proteins (Akassoglou et al., 2000), phagocytose myelin, migrate, and provide scaffolds that are essential for peripheral axon regeneration (Jessen and Mirsky, 2008). The importance of SC viability and migration is highlighted by their ability to create a more permissive environment in the CNS and thereby facilitate nerve regeneration after spinal cord injury (Kuhlengel et al., 1990; Jones et al., 2003). Characterizing the molecular signals that assist in SC survival after nerve
A
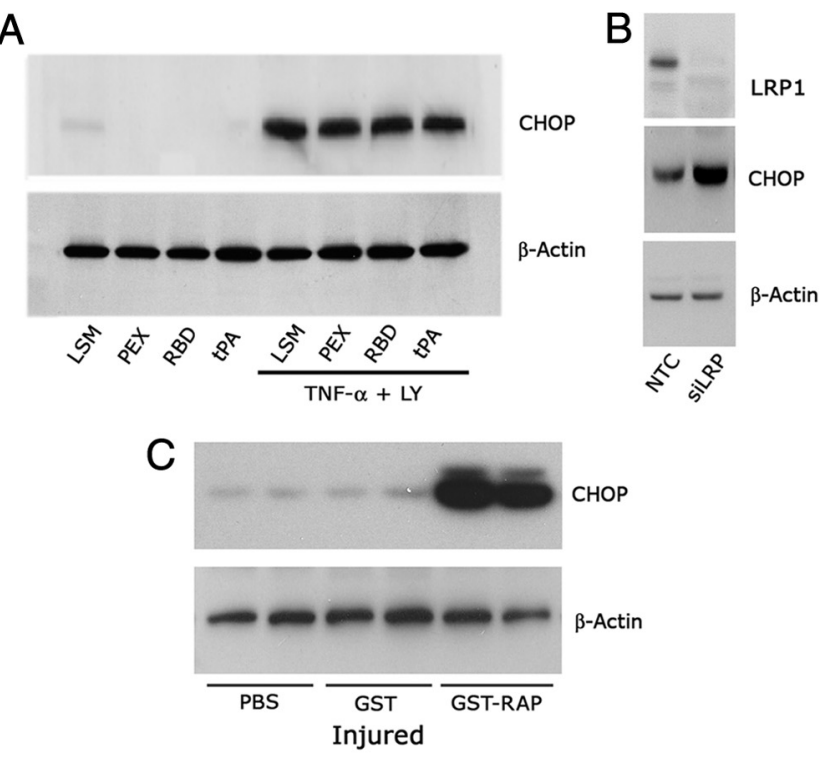

D

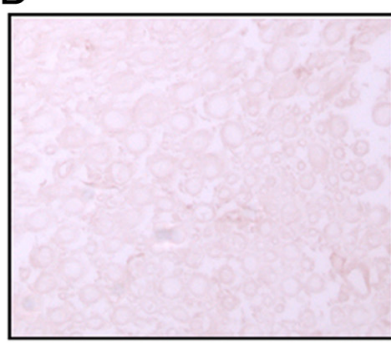

Contralateral

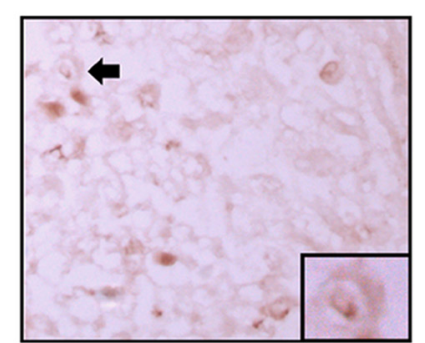

GST

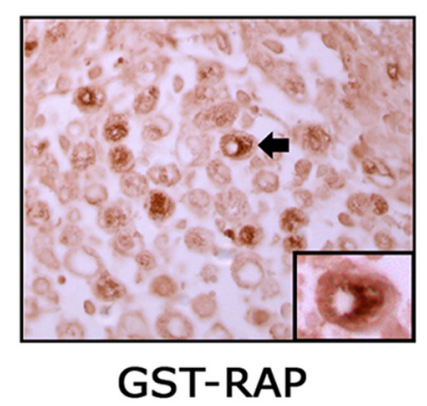

Figure 9. Inhibiting LRP1-dependent PI3K signaling induces CHOP protein expression. $\boldsymbol{A}$, Immunoblot analysis of CHOP from Schwann cells cultured in CM, LSM, or LSM and PEX (10 nM), RBD (10 nM), or IPA (10 nM) for $8 \mathrm{~h}$ with or without LY294002 (20 $\mu \mathrm{M}) \cdot \boldsymbol{B}$, Immunoblot analysis of CHOP in primary cultured Schwann cells transfected with NTC or LRP1-specific siRNA after $18 \mathrm{~h}$ in LSM. C, Immunoblot analysis of CHOP in axotomized rat sciatic nerves injected with $2 \mu \mathrm{l}$ of PBS, GST ( $25 \mu \mathrm{M})$, or GST-RAP ( $25 \mu \mathrm{m}$ ) before axotomy. Nerves were collected and lysed in RIPA buffer supplemented with sodium orthovanadate and proteinase inhibitors after $24 \mathrm{~h}$. Equal amounts of cellular protein $(50 \mu \mathrm{g})$ were loaded into each lane and subjected to SDSPAGE and electrotransferred to nitrocellulose for detection with CHOP antibody. $\beta$-Actin was used as a loading control. The blot represents two rats per group. $\mathbf{D}$, Immunohistochemistry analysis of CHOP in contralateral or axotomized rat sciatic nerves injected with $2 \mu \mathrm{l}$ of GST (25 $\mu \mathrm{M})$ or GST-RAP $(25 \mu \mathrm{M})$ before axotomy.

injury has implications for understanding disease mechanisms in inherited and acquired neuropathies (Berger and Schaumburg, 1995; Suter and Scherer, 2003). However, the signaling pathways that control SC survival remain incompletely elucidated. Many of the growth factors that are produced by SCs immediately after disassociation from axons in the injured PNS, including NT3, PDGF, and IGF-1 (Lobsiger et al., 2000; Jessen and Mirsky, 2005), are 


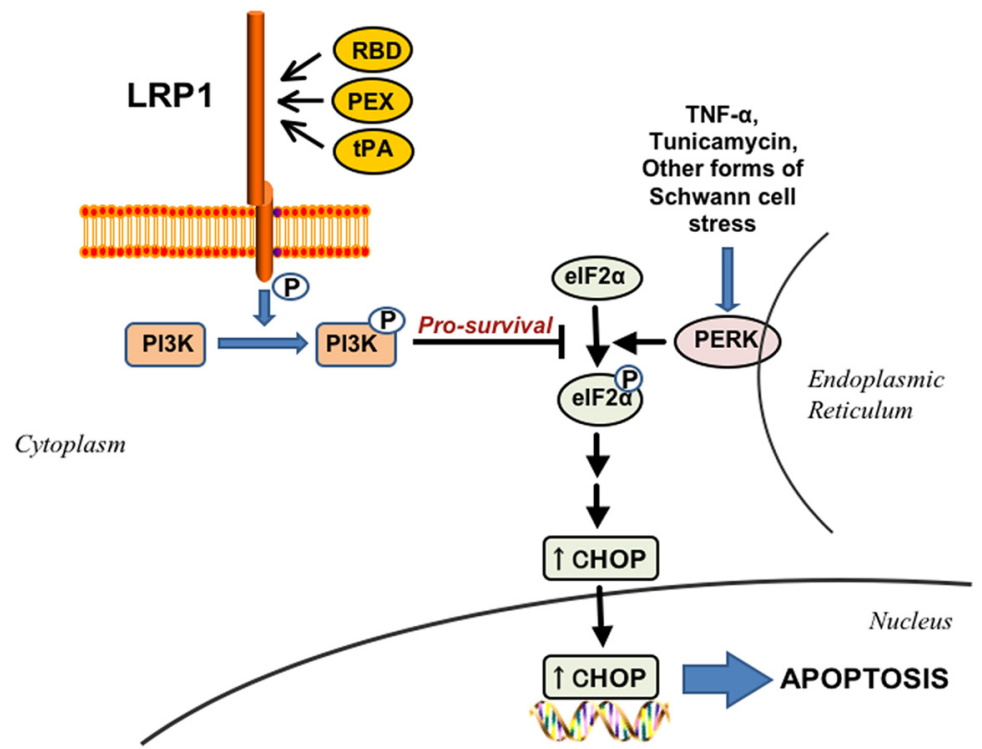

Figure 10. Proposed model of UPR regulation by LRP1. LRP1 activation of PI3K survival signaling antagonizes UPR signaling that would normally culminate in Schwann cell death. CHOP is a major mediator of UPR in Schwann cells.

known to activate PI3K (Campana et al., 1999; Shi et al., 2009; Yamazaki et al., 2009).

Recently, we demonstrated that increased LRP1 expression in peripheral nerve injury is essential for SC survival (Campana et al., 2006). We also have shown that binding of ligands to LRP1 activates Akt in SCs, neurons, and neuron-like cell lines (Campana et al., 2006; Mantuano et al., 2008a,b; Shi et al., 2009). LRP1 transactivates neurotrophin receptors (Shi et al., 2009) and may function as a coreceptor for PDGF (Newton et al., 2005). The multifunctional nature of LRP1 provides numerous candidate mechanisms by which this receptor may support SC survival.

Herein, we have shown that the PERK-CHOP UPR signaling pathway plays a major role in controlling SC survival in vitro and in vivo and that LRP1 is a major regulator of this pathway. Although CHOP is known to be proapoptotic in numerous cells once the UPR is sufficiently advanced (Matsumoto et al., 1996; Zinszner et al., 1998; Maytin et al., 2001; Gotoh et al., 2002; Oyadomari et al., 2002; Marciniak et al., 2004), our work suggests that the PERK-CHOP pathway may be activated in SCs in response to diverse forms of cell stress, including exposure to TNF- $\alpha$. It has been reported that $\mathrm{CHOP}$ expresses diverse activities in myelinating glia. In Pelizaeus-Merzbacher disease, oligodendrocytes express CHOP; however, $\mathrm{CHOP}$ is not necessarily proapoptotic. Instead, $\mathrm{CHOP}$ serves as a biomarker of disease severity and may induce expression of anti-apoptotic genes (Southwood et al., 2002). SCs in an animal model of Charcot-Marie-Tooth disease express CHOP, which apparently promotes demyelination and causes cell death only as a secondary function (Pennuto et al., 2008).

We have shown that, in crush-injured sciatic nerves, early stages of the UPR are activated, as determined by the increase in GRP78/BIP (Bertolotti et al., 2000). When LRP1 is active, the UPR does not progress. Expression of GRP78/BIP in the injured peripheral nerve is consistent with the known ability of adult SCs to compensate for a UPR-inducing microenvironment and survive nerve injury in vivo (Grinspan et al., 1996). Once CHOP levels are increased, SC cell death is promoted. SCs from CHOP gene knock-out mice are less susceptible to TNF- $\alpha$ - and LSMinduced cell death. Although some of these studies were performed using SCs in culture, SC cultures are thought to provide a model of the activated phenotype observed in peripheral nerve injury (Jessen et al., 1990).

The ability of TNF- $\alpha$ to induce phosphorylation of eIF $2 \alpha$ and CHOP protein expression in SCs is an important observation because, in injury to the peripheral nerve, TNF- $\alpha$ is robustly expressed by SCs (Wagner and Myers, 1996) and is a major orchestrator of Wallerian degeneration (Stoll et al., 2002). To our knowledge, these are the first studies demonstrating that a proinflammatory cytokine, known to be involved in demyelination and neuropathic pain, increases CHOP in SCs. Induction of the PERK-CHOP pathway by TNF- $\alpha$ may depend on local physiological concentrations, duration of exposure to cytokine, and activation of interacting signaling pathways in vivo. In response to TNF- $\alpha$, p-eIF $2 \alpha$ and CHOP increased gradually compared with the more rapid changes induced by $\mathrm{TN}$ and LY. The slower kinetics suggest that secondary mediators may be responsible for regulating CHOP. Candidate secondary mediators, which are activated in TNF- $\alpha$-stimulated cells, include reactive oxygen species and PKC $\delta$ (Xue et al., 2005; Greene et al., 2010).

Activation of PI3K by LRP1 emerges as a central pathway that counteracts proapoptotic phases of the UPR in the injured peripheral nerve. When LRP1 activity was blocked with RAP in vivo, PI3K activity was substantially decreased and CHOP was expressed. RAP also significantly increases Schwann cell death in the injured nerve (Campana et al., 2006). LRP1 gene-silencing in SCs in vitro substantially decreased the basal level of phosphoPI3K and increased CHOP levels. Furthermore, diverse LRP1 ligands activated PI3K but inhibited TNF- $\alpha$-induced caspase- 3 activation and cell death. These results support a model in which LRP1-initiated cell signaling is essential to restrict the UPR to the corrective phase in SCs in the injured nerve. When LRP1 is not available, as in RAP-treated cells or when the gene is silenced, CHOP levels increase substantially and SC death occurs.

LRP1 mRNA expression increases substantially in SCs $1 \mathrm{~d}$ after nerve injury in rats (Campana et al., 2006). However, in TNF- $\alpha$ gene knock-out mice, LRP1 expression is not increased, suggesting that LRP1 may play an important role in responding to TNF- $\alpha$ activity in the injured peripheral nerve (Gaultier et al., 2008). Our new findings identify a death-promoting pathway downstream of TNF- $\alpha$ that may be counteracted by LRP1 without inhibition of the ability of TNF- $\alpha$ to induce expression of additional inflammatory cytokines. In doing so, LRP1 may protect cell viability while allowing development of intraneural inflammation. The balance between LRP1 and TNF- $\alpha$ signaling may be shifted in different nerve injury model systems. For example, in neuropathic pain models, such as chronic constriction injury (CCI), higher levels of endoneurial TNF- $\alpha$ are observed compared with crush injury (Kleinschnitz et al., 2004) and cell death also is enhanced (Whiteside and Munglani, 2001). Thus, in a model like CCI, it is possible that the effects of LRP1 on PI3K activity may be insufficient to completely block TNF- $\alpha$-induced SC death. Therapeutic delivery of LRP1 ligands, such as RBD or PEX, may reestablish a more favorable balance between LRP1 
and TNF- $\alpha$ and prevent cytotoxicity even under aggressively proinflammatory conditions such as those modeled by CCI.

Bidirectional crosstalk between UPR signaling and the PI3KAkt pathway has been reported (Hyoda et al., 2006; Yung et al., 2007; Price et al., 2010). Although the ultimate targets of PI3K and Akt that inhibit the UPR in SCs remain incompletely characterized, the prosurvival activity of this pathway is well described (Campana et al., 1999; Weiner and Chun, 1999; Li et al., 2001). Although numerous receptors other than LRP1 also activate PI3K (Echave et al., 2009), our results suggest that LRP1 may play a predominant role in the injured peripheral nerve, perhaps because of the availability of numerous high-affinity LRP1 ligands (Strickland et al., 2002). To the extent that LRP1 is not saturated with endogenously produced ligands in the injured PNS, agents such as the RBD or PEX, which bind specifically to LRP1 with minimal off-target effects, may have therapeutic efficacy (Mantuano et al., 2008b, 2010). Our model demonstrating a central role for LRP1 in PI3K activation and in counteracting the PERK-CHOP signaling pathway is shown in Figure 10.

LRP1 expresses prosurvival activity in a number of cell types, including macrophages, neurons, and cancer cells (Montel et al., 2007; Fuentealba et al., 2009; Yancey et al., 2010). We propose that the prosurvival activity of LRP1 is at least partially explained by its central role in regulating the activity of PI3K. We further propose that counteracting the latter stages of the UPR is a major pathway by which LRP1 and PI3K promote survival of SCs. Overall, we have shown that UPR signaling pathways are significant determinants of SC survival under conditions that are present in the injured peripheral nerve. LRP1 is a major repressor of eIF2 activation and CHOP expression based on its ability to function as a major regulator of PI3K. The effects of LRP1 on CHOP expression may impact not only SC survival in peripheral nerve injury but multiple forms of neuropathology, such as neurodegeneration, in which LRP1 is implicated (Strickland et al., 2002).

\section{References}

Akassoglou K, Kombrinck KW, Degen JL, Strickland S (2000) Tissue plasminogen activator-mediated fibrinolysis protects against axonal degeneration and demyelination after sciatic nerve injury. J Cell Biol 149:1157-1166.

Asbury AK, Johnson PC (1978) Pathology of peripheral nerve. Major Probl Pathol 9:1-311.

Berger AR, Schaumburg HH (1995) Human peripheral nerve disease. In: The axon (Waxman SG, Kocsis JD, Stys PK, eds), pp 648-660. New York: Oxford UP.

Bertolotti A, Zhang Y, Hendershot LM, Harding HP, Ron D (2000) Dynamic interaction of $\mathrm{BiP}$ and ER stress transducers in the unfolded protein response. Nat Cell Biol 2:326-332.

Brunet A, Datta SR, Greenberg ME (2001) Transcription-dependent and -independent control of neuronal survival by the PI3K-Akt signaling pathway. Curr Opin Neurobiol 11:297-305.

Campana WM (2007) Schwann cells: activated peripheral glia and their role in neuropathic pain. Brain Behav Immun 21:522-527.

Campana WM, Hiraiwa M, O’Brien JS (1998) Prosaptide activates the MAPK pathway by a G-protein-dependent mechanism essential for enhanced sulfatide synthesis by Schwann cells. FASEB J 12:307-314.

Campana WM, Darin SJ, O’Brien JS (1999) Phosphatidylinositol 3-kinase and Akt protein kinase mediate IGF-I- and prosaptide-induced survival in Schwann cells. J Neurosci Res 57:332-341.

Campana WM, Li X, Dragojlovic N, Janes J, Gaultier A, Gonias SL (2006) The low-density lipoprotein receptor-related protein is a prosurvival receptor in Schwann cells: possible implication in peripheral nerve injury. J Neurosci 26:11197-11207.

Chan JR, Cosgaya JM, Wu YJ, Shooter EM (2001) Neurotrophins are key mediators of the myelination program in the peripheral nervous system. Proc Natl Acad Sci U S A 98:14661-14668.

Echave P, Machado-da-Silva G, Arkell RS, Duchen MR, Jacobson J, Mitter R,
Lloyd AC (2009) Extracellular growth factors and mitogens cooperate to drive mitochondrial biogenesis. J Cell Sci 122:4516-4525.

Fuentealba RA, Liu Q, Kanekiyo T, Zhang J, Bu G (2009) Low density lipoprotein receptor-related protein 1 promotes anti-apoptotic signaling in neurons by activating Akt survival pathway. J Biol Chem 284:34045-34053.

Gaultier A, Arandjelovic S, Niessen S, Overton CD, Linton MF, Fazio S, Campana WM, Cravatt BF 3rd, Gonias SL (2008) Regulation of tumor necrosis factor receptor-1 and the IKK-NF-kappaB pathway by LDL receptor-related protein explains the antiinflammatory activity of this receptor. Blood 111:5316-5325.

Gotoh T, Oyadomari S, Mori K, Mori M (2002) Nitric oxide-induced apoptosis in RAW 264.7 macrophages is mediated by endoplasmic reticulum stress pathway involving ATF6 and CHOP. J Biol Chem 277:12343-12350.

Gow A, Wrabetz L (2009) CHOP and the endoplasmic reticulum stress response in myelinating glia. Curr Opin Neurobiol 19:505-510.

Greene MW, Ruhoff MS, Burrington CM, Garofalo RS, Oreña SJ (2010) TNF- $\alpha$ activation of PKCdelta, mediated by NFKappaB and ER stress, cross talks with the insulin signaling cascade. Cell Signal 22:274-284.

Grinspan JB, Marchionni MA, Reeves M, Coulaloglou M, Scherer SS (1996) Axonal interactions regulate Schwann cell apoptosis in developing peripheral nerve: neuregulin receptors and the role of neuregulins. J Neurosci 16:6107-6118.

Harding HP, Zhang Y, Bertolotti A, Zeng H, Ron D (2000a) Perk is essential for translational regulation and cell survival during the unfolded protein response. Mol Cell 5:897-904.

Harding HP, Novoa I, Zhang Y, Zeng H, Wek R, Schapira M, Ron D (2000b) Regulated translation initiation controls stress-induced gene expression in mammalian cells. Mol Cell 6:1099-1108.

Harding HP, Calfon M, Urano F, Novoa I, Ron D (2002) Transcriptional and translational control in the mammalian unfolded protein response. Annu Rev Cell Dev Biol 18:575-599.

Herz J, Goldstein JL, Strickland DK, Ho YK, Brown MS (1991) 39-kDa protein modulates binding of ligands to low density lipoprotein receptor-related protein $/ \alpha 2$-macroglobulin receptor. J Biol Chem 266:21232-21238.

Honkanen H, Lahti O, Nissinen M, Myllylä RM, Kangas S, Päiväläinen S, Alanne MH, Peltonen S, Peltonen J, Heape AM (2007) Isolation, purification and expansion of myelination-competent, neonatal mouse Schwann cells. Eur J Neurosci 26:953-964.

Hyoda K, Hosoi T, Horie N, Okuma Y, Ozawa K, Nomura Y (2006) PI3KAkt inactivation induced CHOP expression in endoplasmic reticulumstressed cells. Biochem Biophys Res Commun 340:286-290.

Jessen KR, Mirsky R (2005) The origin and development of glial cells in peripheral nerves. Nat Rev Neurosci 6:671-682.

Jessen KR, Mirsky R (2008) Negative regulation of myelination: relevance for development, injury, and demyelinating disease. Glia 56:1552-1565.

Jessen KR, Morgan L, Stewart HJ, Mirsky R (1990) Three markers of adult non-myelin forming Schwann cells, 217c (Ran-1), A5E3 and GFAP: development and regulation by neuron Schwann cell interactions. Development 109:91-103.

Jones LL, Sajed D, Tuszynski MH (2003) Axonal regeneration through regions of chondroitin sulfate proteoglycan deposition after spinal cord injury: a balance of permissiveness and inhibition. J Neurosci 23:9276-9288.

Kleinschnitz C, Brinkhoff J, Zelenka M, Sommer C, Stoll G (2004) The extent of cytokine induction in peripheral nerve lesions depends on the mode of injury and NMDA receptor signaling. J Neuroimmunol 149:77-83.

Kuhlengel KR, Bunge MB, Bunge RP (1990) Implantation of cultured sensory neurons and Schwann cells into lesioned neonatal rat spinal cord. I. Methods for preparing implants from dissociated cells. J Comp Neurol 293:63-73.

La Fleur M, Underwood JL, Rappolee DA, Werb Z (1996) Basement membrane and repair of injury to peripheral nerve: defining a potential role of macrophages matrix metalloproteinase and tissue inhibitor of metalloproteinases-1. J Exp Med 184:2311-2326.

Li X, Gonias SL, Campana WM (2005) Schwann cells express erythropoietin receptor and represent a major target for Epo in peripheral nerve injury. Glia 51:254-265.

Li Y, Tennekoon GI, Birnbaum M, Marchionni MA, Rutkowski JL (2001) Neuregulin signaling through a PI3K/Akt/Bad pathway in Schwann cell survival. Mol Cell Neurosci 17:761-767. 
Lin JH, Li H, Yasumura D, Cohen HR, Zhang C, Panning B, Shokat KM, Lavail MM, Walter P (2007) IRE1 signaling affects cell fate during the unfolded protein response. Science 318:944-949.

Lin JH, Li H, Zhang Y, Ron D, Walter P (2009) Divergent effects of PERK and IRE1 signaling on cell viability. PLoS One 4:e4170.

Livak KJ, Schmittgen TD (2001) Analysis of relative gene expression data using real-time quantitative PCR and the $2-\Delta \Delta C T$ method. Methods 25:402-408.

Lobsiger CS, Schweitzer B, Taylor V, Suter U (2000) Platelet Derived Growth Factor-BB supports the survival of cultured Schwann cell precursors in synergy with neurotrophin 3. Glia 30:290-300.

Macdonald R, Bingham S, Bond BC, Parsons AA, Philpott KL (2001) Determination of changes in mRNA expression in a rat model of neuropathic pain by Taqman quantitative RT-PCR. Mol Brain Res 90:48-56.

Mantuano E, Mukandala G, Li X, Campana WM, Gonias SL (2008a) Molecular dissection of the human $\alpha$-2macroglobulin subunit reveals domains with antagonistic activities in cell signaling. J Biol Chem 283:19904-19911.

Mantuano E, Inoue G, Li X, Takahashi K, Gaultier A, Gonias SL, Campana WM (2008b) The hemopexin domain of matrix metalloproteinase-9 activates cell signaling and promotes migration of Schwann cells by binding to low-density lipoprotein receptor-related protein. J Neurosci 28:11571-11582.

Mantuano E, Jo M, Gonias SL, Campana WM (2010) Low density lipoprotein receptor-related protein (LRP1) regulates Racl and RhoA reciprocally to control Schwann cell adhesion and migration. J Biol Chem 285:14259-14266.

Marciniak SJ, Yun CY, Oyadomari S, Novoa I, Zhang Y, Jungreis R, Nagata K, Harding HP, Ron D (2004) CHOP induces death by promoting protein synthesis and oxidation in the stressed endoplasmic reticulum. Genes Dev 18:3066-3077.

Matsumoto M, Minami M, Takeda K, Sakao Y, Akira S (1996) Ectopic expression of CHOP (GADD153) induces apoptosis in M1 myeloblastic leukemia cells. FEBS Lett 395:143-147.

Maytin EV, Ubeda M, Lin JC, Habener JF (2001) Stress-inducible transcription factor $\mathrm{CHOP} /$ gadd 153 induces apoptosis in mammalian cells via p38 kinase-dependent and -independent mechanisms. Exp Cell Res 267:193-204

Meier C, Parmantier E, Brennan A, Mirsky R, Jessen KR (1999) Developing Schwann cells acquire the ability to survive without axons by establishing an autocrine circuit involving insulin-like growth factor, neurotrophin-3, and platelet-derived growth factor-BB. J Neurosci 19:3847-3859.

Mettenburg JM, Webb DJ, Gonias SL (2002) Distinct binding sites in the structure of alpha 2-macroglobulin mediate the interaction with betaamyloid peptide and growth factors. J Biol Chem 277:13338-13345.

Meyer M, Matsuoka I, Wetmore C, Olson L, Thoenen H (1992) Enhanced synthesis of brain-derived neurotrophic factor in the lesioned peripheral nerve: different mechanisms are responsible for the regulation of BDNF and NGF mRNA. J Cell Biol 119:45-54.

Montel V, Gaultier A, Lester RD, Campana WM, Gonias SL (2007) The low-density lipoprotein receptor-related protein regulates cancer cell survival and metastasis development. Cancer Res 67:9817-9824.

Mounir Z, Krishnamoorthy JL, Robertson GP, Scheuner D, Kaufman RJ, Georgescu MM, Koromilas AE (2009) Tumor suppression by PTEN requires the activation of the PKR-eIF2alpha phosphorylation pathway. Sci Signal 2:ra85.

Myers RR, Sekiguchi Y, Kikuchi S, Scott B, Medicherla S, Protter A, Campana WM (2003) Inhibition of p38 MAP kinase activity enhances axonal regeneration. Exp Neurol 184:606-614.

Newton CS, Loukinova E, Mikhailenko I, Ranganathan S, Gao Y, Haudenschild C, Strickland DK (2005) Platelet-derived growth factor receptorbeta (PDGFR-beta) activation promotes its association with the low density lipoprotein receptor-related protein (LRP). Evidence for coreceptor function. J Biol Chem 280:27872-27878.

Oyadomari S, Mori M (2004) Roles of CHOP/GADD153 in endoplasmic reticulum stress. Cell Death Differ 11:381-389.

Oyadomari S, Koizumi A, Takeda K, Gotoh T, Akira S, Araki E, Mori M (2002) Targeted disruption of the Chop gene delays endoplasmic reticulum stress-mediated diabetes. J Clin Invest 109:525-532.

Pennuto M, Tinelli E, Malaguti M, Del Carro U, D’Antonio M, Ron D, Quattrini A, Feltri ML, Wrabetz L (2008) Ablation of the UPR-mediator $\mathrm{CHOP}$ restores motor function and reduces demyelination in CharcotMarie-Tooth 1B mice. Neuron 57:393-405.
Price J, Zaidi AK, Bohensky J, Srinivas V, Shapiro IM, Ali H (2010) Akt-1 mediates survival of chondrocytes from endoplasmic reticulum-induced stress. J Cell Physiol 222:502-508.

Ron D, Walter P (2007) Signal integration in the endoplasmic reticulum unfolded protein response. Nat Rev Mol Cell Biol 8:519-529.

Shi Y, Mantuano E, Inoue G, Campana WM, Gonias SL (2009) Ligand binding to LRP1 transactivates Trk receptors by a Src family kinase-dependent pathway. Sci Signal 2:ra18.

Shi Y, Yamauchi T, Gaultier A, Takimoto S, Campana WM, Gonias SL (2011) Regulation of cytokine expression by Schwann cells in response to a2-macroglobulin binding to LRP1. J Neurosci Res 89:544-551.

Shubayev VI, Angert M, Dolkas J, Campana WM, Palenscar K, Myers RR (2006) TNF $\alpha$-induced MMP-9 promotes macrophage recruitment into injured peripheral nerve. Mol Cell Neurosci 31:407-415.

Sommer C, Schäfers M (1998) Painful mononeuropathy in C57BL/Wld mice with delayed Wallerian degeneration: differential effects of cytokine production and nerve regeneration on thermal and mechanical hypersensitivity. Brain Res 784:154-162.

Southwood CM, Garbern J, Jiang W, Gow A (2002) The unfolded protein response modulates disease severity in Pelizaeus-Merzbacher disease. Neuron 36:585-596.

Stoll G, Jander S, Myers RR (2002) Degeneration and regeneration of the peripheral nervous system: from Augustus Waller's observations to neuroinflammation. J Peripher Nerv Syst 7:13-27.

Strickland DK, Gonias SL, Argraves WS (2002) Diverse roles for the LDL receptor family. Trends Endocrinol Metab 13:66-74.

Suter U, Scherer SS (2003) Disease mechanisms in inherited neuropathies. Nat Rev Neurosci 4:714-726.

Thornberry NA, Lazebnik Y (1998) Caspases: enemies within. Science 281:1312-1316.

Wagner R, Myers RR (1996) Endoneurial injection of TNF-alpha produces neuropathic pain behaviors. Neuroreport 7:2897-2901.

Wagner R, Myers RR, O’Brien JS (1998) Prosaptide prevents hyperalgesia and reduces peripheral TNFR1 expression following TNF-alpha nerve injection. Neuroreport 9:2827-2831.

Weiner JA, Chun J (1999) Schwann cell survival mediated by the signaling phospholipid lysophosphatidic acid. Proc Natl Acad Sci U S A 96: 5233-5238

Whiteside GT, Munglani R (2001) Cell death in the superficial dorsal horn in a model of neuropathic pain. J Neurosci Res 64:168-173.

Willnow TE, Rohlmann A, Horton J, Otani H, Braun JR, Hammer RE, Herz J (1996) RAP, a specialized chaperone, prevents ligand-induced ER retention and degradation of LDL receptor-related endocytic receptors. EMBO J 15:2632-2639.

Winnay JN, Boucher J, Mori MA, Ueki K, Kahn CR (2010) A regulatory subunit of phosphoinositide 3-kinase increases the nuclear accumulation of X-box-binding protein-1 to modulate the unfolded protein response. Nat Med 16:438-445.

Xue X, Piao JH, Nakajima A, Sakon-Komazawa S, Kojima Y, Mori K, Yagita H, Okumura K, Harding H, Nakano H (2005) Tumor necrosis factor $(\mathrm{TNF} \alpha)$ induces the unfolded protein response (UPR) in a reactive oxygen species (ROS)-dependent fashion, and the UPR counteracts ROS accumulation by TNF $\alpha$. J Biol Chem 280:33917-33925.

Yamazaki T, Sabit H, Oya T, Ishii Y, Hamashima T, Tokunaga A, Ishizawa S, Jie S, Kurashige Y, Matsushima T, Furuta I, Noguchi M, Sasahara M (2009) Activation of MAP kinases, Akt and PDGF receptors in injured peripheral nerves. J Peripher Nerv Syst 14:165-176.

Yancey PG, Blakemore J, Ding L, Fan D, Overton CD, Zhang Y, Linton MF, Fazio S (2010) Macrophage LRP-1 controls plaque cellularity by regulating efferocytosis and Akt activation. Arterioscler Thromb Vasc Biol 30:787-795.

Yung HW, Korolchuk S, Tolkovsky AM, Charnock-Jones DS, Burton G] (2007) Endoplasmic reticulum stress exacerbates ischemia-reperfusioninduced apoptosis through attenuation of Akt protein synthesis in human choriocarcinoma cells. FASEB J 21:872-884.

Zhang JY, Luo XG, Xian CJ, Liu ZH, Zhou XF (2000) Endogenous BDNF is required for myelination and regeneration of injured sciatic nerve in rodents. Eur J Neurosci 12:4171-4180.

Zinszner H, Kuroda M, Wang X, Batchvarova N, Lightfoot RT, Remotti H, Stevens JL, Ron D (1998) CHOP is implicated in programmed cell death in response to impaired function of the endoplasmic reticulum. Genes Dev 12:982-995. 